\title{
DEMYELINATION INDUCED BY MURINE CORONAVIRUS JHM INFECTION OF CONGENITALLY IMMUNODEFICIENT MICE
}

\author{
J. J. Houtman, ${ }^{1}$ H. C. Hinze, ${ }^{1}$ and J. O. Fleming ${ }^{1,2,3}$ \\ ${ }^{1}$ Departments of Medical Microbiology and Immunology \\ ${ }^{2}$ Department of Neurology \\ University of Wisconsin School of Medicine \\ ${ }^{3}$ William S. Middleton Memorial Veterans Hospital \\ Madison, Wisconsin
}

\begin{abstract}
Mouse hepatitis virus JHM (JHMV or MHV-4) induces demyelination in rodents and has been studied as a model for the human disease, multiple sclerosis (MS). As is proposed in MS, the mechanism of subacute demyelination induced by JHMV appears to be primarily immunopathological, since demyelination in JHMV-infected mice is abrogated by immunosuppressive doses of irradiation and restored by adoptive transfer of splenocytes. Thy $-1^{+}$ cells play a critical role in transmitting disease to these recipient mice. To further characterize cells which may mediate JHMV-induced immunopathology, we inoculated congenitally immunodeficient mice with JHMV. By 12 days post-inoculation, both immunocompetent $\mathrm{C} 57 \mathrm{BL} / 6 \mathrm{~J}$ controls and athymic nude $\mathrm{C} 57 \mathrm{BL} / 6$ mice had severe paralysis and demyelination. In marked contrast, C57BL/6 mice with the severe combined immune deficiency (SCID) mutation had little or no paralysis or demyelination. Adoptive transfer of immune spleen cells from nude mice to infected SCID mice produced paralysis and demyelination. These findings suggest that a cell population present in immunocompetent $\mathrm{C} 57 \mathrm{BL} / 6 \mathrm{~J}$ and nude mice but absent or non-functional in irradiated and SCID mice is essential for JHMV-induced demyelination. Identification of cells which mediate demyelination in this experimental system may have implications for our understanding of coronavirus pathogenesis and human demyelinating diseases.
\end{abstract}

\section{INTRODUCTION}

Infection of rodents with the neurotropic murine coronavirus JHM (MHV-4) produces an acute, often lethal encephalitis. Survivors exhibit a subacute or chronic paralytic- 
demyelinating disease which has been proposed as a model for the human demyelinating disease, multiple sclerosis.

Two mechanisms for JHMV-induced demyelination have been proposed. Early studies suggested that myelin damage was due to cytolytic viral infection of the myelin-producing oligodendrocytes ${ }^{1,2}$. Support for the oligodendrocyte lysis hypothesis included the localization of virions within oligodendrocytes and the occurrence of some demyelination in immunosuppressed mice. More recently, however, evidence has accumulated supporting a mechanism whereby myelin damage is caused by the immune response to viral infection. Immunosuppressive irradiation up to six days post-inoculation (PI) can prevent demyelination and adoptive transfer of immune splenocytes restores demyelination to infected irradiated recipients ${ }^{3}$. In addition, depletion of cells bearing the Thy-1 marker from the adoptively transferred cell population prevents restoration of demyelination, suggesting a role for $\mathrm{T}$ lymphocytes in demyelination ${ }^{4}$. An immunopathological mechanism for JHMV-induced demyelination has also been demonstrated in rats, with both $\mathrm{CD}^{+}$and $\mathrm{CD} 8^{+} \mathrm{T}$ lymphocytes contributing to disease ${ }^{5}$.

To characterize cells which may participate in immune-mediated demyelination, we infected congenitally immunodeficient mice with JHMV. Athymic nude mice developed paralysis and demyelination. In contrast, mice possessing the severe combined immune deficiency (SCID) mutation showed minimal paralysis and little or no demyelination. In addition, demyelination was adoptively transferred to infected SCID mice with immune splenocytes from nude mice. This supports an immunopathological mechanism for demyelination and suggests that a cell population present in immunocompetent and nude mice but absent or non-functional in SCID and irradiated mice is essential for JHMV-induced demyelination.

\section{MATERIALS AND METHODS}

Male C57BL/6J, C57BL/6J-nu (nude) and C57BL/6J-scid/SzJ (SCID) mice were obtained from The Jackson Laboratory (Bar Harbor, ME) and used at 5-7 weeks of age. Mice were housed in microisolators and handled in a biosafety hood. The neuroattenuated JHMV antigenic variant $2.2-\mathrm{V}-1$ has been described previously and produces demyelination in immunocompetent mice with little or no encephalitis ${ }^{6,7}$. Mice were infected with $10^{3}$ plaque forming units ( $\mathrm{pfu}$ ) of virus in $30 \mu \mathrm{l}$ of Dulbecco's modified essential medium (DMEM) by the intracerebral (i.c.) route. Selected mice were irradiated 3 days after intracerebral inoculation with 850 rads of gamma-irradiation from a Cobalt- 60 source $^{4}$. Donor nude mice were immunized with $10^{6} \mathrm{PFU}$ intraperitoneally 6 days prior to transfer. Recipient SCID mice were infected 3 days prior to transfer. Donor splenocytes $\left(4 \times 10^{6}\right.$ cells) were transferred by the intravenous route.

Mice were monitored for clinical signs of disease until 12 days PI, when they were sacrificed. Brains and spinal cords were removed and subjected to virus isolation on DBT cells $^{8}$ or histopathological analysis ${ }^{9}$. A combined hematoxylin and eosin/luxol fast blue stain was used to visualize myelin. Selected mice were perfused for electron microscopic analy$\operatorname{sis}^{6}$.

\section{RESULTS}

As has been demonstrated previously, immunocompetent C57BL/6J mice infected with 2.2-V-1 undergo severe paralysis accompanied by marked demyelination, which can be prevented by immunosuppressive irradiation 3 days post-inoculation (Table 1, Groups 1 
titers of infectious virus in the CNS at 12 days PI. This argues against a viral cytolytic mechanism for JHMV-induced demyelination.

At 12 days PI, we isolated infectious virus from the brains of irradiated C57BL/6 mice, nude and SCID mice, and SCID recipients of immune nude splenocytes. Only 1mmunocompetent C57BL/6 mice were able to clear infectious virus by 12 days PI. This is consistent with reports demonstrating a requirement for $\mathrm{CD}^{+}$and $\mathrm{CD} 8^{+} \mathrm{T}$ lymphocytes for viral clearance ${ }^{12,13}$. Since nude mice developed severe paralysis and demyelination, yet were unable to clear the virus, distinct cell populations may be involved in demyelination and viral clearance. Although $\mathrm{T}$ lymphocytes are essential for demyelination ${ }^{4}$, thymically educated $\mathrm{T}$ lymphocytes do not appear to be required, since athymic nude mice develop severe demyelination.

In conclusion, we have demonstrated paralysis and demyelination in JHMV-infected immunocompetent and nude mice. In contrast, little or no demyelination was evident in SCID and irradiated mice. Adoptive transfer of immune splenocytes from nude mice resulted in paralysis and demyelination in SCID recipients. Our findings support an immune-mediated mechanism for demyelination. and suggest that a cell population present in immunocompetent and nude mice, but deficient in SCID and irradiated mice, is essential for JHMV-induced demyelination. Identification of this cell population may lead to new insights into the pathogenesis of human demyelinating diseases.

\section{ACKNOWLEGEMENTS}

This work was supported by the National Multiple Sclerosis Society (grant RG-2153A-2). J.J.H. is a trainee on NIH Cellular and Molecular Biology Training Grant GM07215.

\section{REFERENCES}

1 Lampert, P W, Sıms, J K, Knıazeff, A J Mechanısm of demyelınatıon in JHM virus encephalomyelıtıs Electron microscopic studies Acta Neuropath (Berlın) 1973,24 76-85

2 Weiner, L P Pathogenesis of demyelınation induced by a mouse hepatıtıs virus (JHM virus) Arch Neurol 1973,28 298-303

3 Wang, F -I , Stohlman, S A, Flemıng, J O Demyelınatıon induced by murıne hepatıtıs virus JHM straın (MHV-4) is immunologically mediated J Neuroimmunol 1990,30 31-41

4 Flemıng, J O, Wang, F -I , Trousdale, M D, Hinton, D R, Stohlman, S A Interaction of immune and central nervous systems Contribution of antı-viral Thy- $1^{+}$cells to demyelınation induced by coronavirus JHM Regional Immunol 1993,5 37-43

5 Schwender, S, Hein, A, Imrich, H, Dorries, R On the role of different lymphocyte subpopulations in the course of coronavirus MHV IV (JHM)-induced encephalitis in Lewis rats In Laude, H, Vautherot, J F (eds) Coronaviruses Plenum Press, NY 1994 pp 425-430

6 Flemıng, J O, Trousdale, M.D, El-Zaatarı, F A K, Stohlman, S A, Weiner L P Pathogenıcity of antıgenıc varıants of murıne coronavirus JHM selected with monoclonal antıbodies J Virol 1986,58 869875

7 Flemıng, J O , Trousdale, M D , Bradbury, J , Stohlman, S A, Weıner, L P Experımental demyelınation induced by coronavirus JHM (MHV-4) Molecular identıfication of a viral determınant of paralytıc disease Microb Pathogen 1987,3 9-20

8 Stohlman, S A, Matsushıma, G K, Casteel, N, Weiner, L P In vivo effects of coronavirus-specific T cell clones DTH inducer cells prevent a lethal infection but do not inhibit virus replication $\mathrm{J}$ Immunol 1986,136 3052-3056

9 Wang, F-I , Hinton, D R, Gilmore, W, Trousdale, M D, Flemıng, J O Sequential infection of glial cells by the murine hepatitıs virus JHM strain (MHV-4) leads to a characteristic distribution of demyelination Lab Invest 1992,66 744-754 
10 Sorensen, O, Dugre, R, Percy, D, Dales, S In vivo and in vitro models of demyelinatıng disease Endogenous factors influencing demyelinating disease caused by mouse hepatitis virus in rats and mice Infect Immun 1982,1248-1260

11 Sorensen, O, Saravanı, A, Dales, S In vivo and in vitro models of demyelınatıng disease XVII The infectious process in athymic rats inoculated with JHM virus Microb Pathogen 1987,2 79-90

12 Sussman, M A, Shubın, R A, Kyuwa, S, Stohlman, S A T-cell-mediated clearance of mouse hepatitıs virus strain JHM from the central nervous system J Virol 1989,63 3051-3056

13 Williamson, J S P, Stohlman, S A Effectıve clearance of mouse hepatitıs virus from the central nervous system requires both $\mathrm{CD}^{+}$and $\mathrm{CD}^{+} \mathrm{T}$ cells $\mathrm{J}$ Virol 1990,64 4589-4592. 